九州大学学術情報リポジトリ

Kyushu University Institutional Repository

\title{
A Rice Nematode Disease "Senchu Shingare Byo": II. Hibernation of Aphelenchoides oryzae
}

Yoshii, Hazime

Laboratory of Plant Pathology, Department of Agriculture, Kyushu University

Yamamoto, Shigeo

Laboratory of Plant Pathology, Department of Agriculture, Kyushu University

https://doi.org/10.5109/22626

出版情報 : 九州大学大学院農学研究院紀要. 9 (3)，pp.223-233，1950-01. Kyushu University バージョン：

権利関係 : 


\section{A RICE NEMATODE DISEASE, "SENCHÔ SHINGARE BYÔ" "1)}

II. Hibernation of Aphelenchoides oryzae $e^{2}$

Haziml: Yoshit and Shigeo Yamamoto

\section{Distribution OF THE NEMATODES ON THE AfFected Rice Plant}

Before the time of ear formation the nematodes are found in the interior of the folded young leaf, without having any definite position or not restricted to the part about the apical meristem of a leaf. Population of the nematode at this time is thin, and it is often difficult to find the nematode.

The nematodes are often found within the pubescence of young spikclets after the beginning of ear formation. Sometimes however, they are found in the interior of the flowering glumes. The nematodes are always exo-parasitic and do not enter the meristematic tissues of panicles or leaves.

At the earing stage, the majority of the nematodes still are found on the exterior of glumes or within the pubescence of panicles, as pointed out by Fukano and Yokoyama (1947). Many of the nematodes enter the interior of flowering giume at the time of inflorescence, though some of them are found already in the inner side of the palea before the emergence of panicles from the sheath.

1) Contribution from the Laboratury of Plant Pathology, Kyushu University.

2) I. Symptom and Pathogenic Nematode. four. Facult. Agr., Kyushu Univ., Vol. 9. No. 3,1950 . 


\section{Distribution of the Nematodes on Mature Grain}

To compare the population of the nematodes which exist on the outer side of unhulled-grain with that in the inner side of the husk, 20 unhulled-grains from the affected plants were soaked in water overnight at $25^{\circ} \mathrm{C}$, and let the outside nematodes wriggle out into the water. The residual unhulled-grains were gathered and washed. Thus, the number of nematodes in the interior of the husks was counted in the usual manner. ${ }^{1)}$ The results obtained with ten replicates, given in Table 1 , indicate that the number of nematodes in the interior of the husks is much larger than on the exterior of unhulled-grains.

Table 1. Distribution of the nematode out- and inside of unhulled-grain. 10 replicates of 20 grains each.

\begin{tabular}{|c|c|c|}
\hline \multicolumn{2}{|c|}{$\begin{array}{l}\text { Number of nematodes } \\
\text { outside of husks }\end{array}$} & \multirow{2}{*}{$\begin{array}{c}\text { Number of nematodes } \\
\text { inside of husks }\end{array}$} \\
\hline & 6 & \\
\hline & 2 & 21 \\
\hline & 1 & 29 \\
\hline & 0 & 26 \\
\hline & 3 & 18 \\
\hline & 0 & 22 \\
\hline & 0 & 26 \\
\hline & 1 & 24 \\
\hline & 3 & 28 \\
\hline & 0 & 87 \\
\hline Total & 16 & 311 \\
\hline Mean & 1.6 & 31.1 \\
\hline$D \geq 19$ & $\begin{array}{l}\text { Difference bet } \\
1 \text { per cent les }\end{array}$ & significant at \\
\hline
\end{tabular}

In the inner side of mature glume the nematode usually coiled up and stuck to the inner wall of the flowering glume. The number of nematodes of the grain-side is less than that of glumeside when examined after the grain was hulled (Table 2).

1) Ten to twenty unhulled-grains are stripped of their husks. Materials thus obtained are put in a test tube, into which one cc. of distilled water is poured. Thus about 20 tubes are prepared for one lot. After being kept at $25^{\circ} \mathrm{C}$. for 16 to 20 hours, the materials in each lube are poured into a watch glass. The numbers of both moving (living! and immobile (dead) nematode are counted under a binocular microscope. 
Table 2. Comparison between numbers of nematodes on hull-side and on grain-side.

15 replicates of 10 grains each.

\begin{tabular}{|c|c|c|c|c|}
\hline \multicolumn{3}{|c|}{$\begin{array}{c}\text { Number of nematodes } \\
\text { on hulled-grains }\end{array}$} & \multicolumn{2}{|c|}{$\begin{array}{c}\text { Number of nematode } \\
\text { on hulls (husks) }\end{array}$} \\
\hline & Living & Total & Living & Total \\
\hline \multirow{15}{*}{. } & 0 & 10 & 12 & 19 \\
\hline & 0 & 12 & 8 & 14 \\
\hline & 0 & 6 & 17 & 27 \\
\hline & 0 & 1 & 22 & 37 \\
\hline & (1) & 7 & 18 & 23 \\
\hline & ) & 13 & 22 & 36 \\
\hline & 0 & 9 & 19 & 27 \\
\hline & 0 & 10 & 9 & 15 \\
\hline & 0 & 7 & 8 & 17 \\
\hline & 0 & 13 & 1] & 21 \\
\hline & 0 & 7 & 19 & 23 \\
\hline & 0 & 13 & 15 & 21. \\
\hline & 0 & 7 & 12 & 17 \\
\hline & 0 & 3 & 22 & 28 \\
\hline & 0 & 6 & Lí1 & 19 \\
\hline Total & 0 & 124 & 228 & 344 \\
\hline Mean & & 8.3 & & 22.9 \\
\hline
\end{tabular}

$D \geq 5.6$ Difference between means significant at i per cent level.

The number of the rematodes found on well-developed unhulledgrain is larger than those on waste unhulled-grain, "Shiina "1" (Table 3).

Table 3. Comparison between numbers of the nematode th well-cleveloped grains and on waste grains. 15 replicates of 10 grains each.

\begin{tabular}{|c|c|c|c|c|}
\hline \multicolumn{2}{|c|}{ Selected unhulled-grains } & \multicolumn{3}{|c|}{ Waste unhulled-grains, Shima } \\
\hline $\begin{array}{l}\text { Living } \\
\text { nematode }\end{array}$ & $\begin{array}{c}\text { Total } \\
\text { nematode }\end{array}$ & & $\begin{array}{l}\text { Living } \\
\text { nematode }\end{array}$ & $\begin{array}{l}\text { Total } \\
\text { nematode }\end{array}$ \\
\hline 12 & 29 & & 0 & 23 \\
\hline 8 & 26 & & 3 & 35 \\
\hline 17 & 33 & & () & 30 \\
\hline 22 & 38 & & 0 & 9 \\
\hline 18 & 30 & & 10 & 28 \\
\hline
\end{tabular}

1) "Shiina" is a sort of unhulled-gxain cumposed of imperfect amr mmatme grain and of empty spikelet. Shina is usually driven away fom ripe grain by a winnowing.fan. 


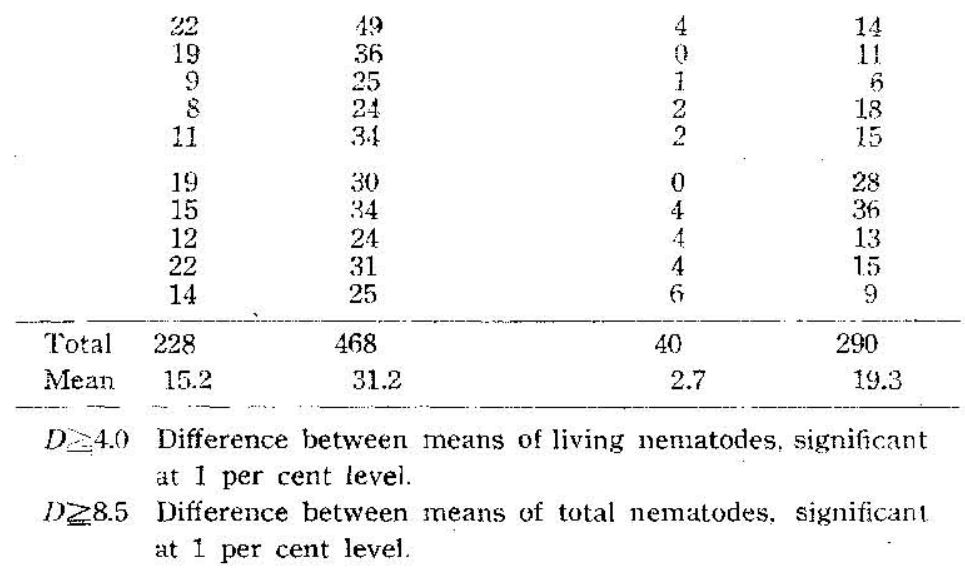

\section{Distribution OF THE Nematode ON RICE STRAW}

In May 1949, 170 culms (with leaves) of rice heavily affected in the preceding season, were divided into five portions after leafblades were clipped off (Table 4). From the ground materials of each of these five parts, 1) $0.05,2$ ) $0.2,3) 0.6,4) 0.7$, and 5 ) 0.8 grams were weighed out respectively, and the nematode numbers within each part were counted.

Table 4. Method of partition of culms with sheatls to count the nematode number.

\begin{tabular}{|c|c|c|}
\hline I'att No. & Sort of materials & Weight (gm.) \\
\hline 1 & $\begin{array}{l}\text { Grain residual at thrashing, maitly of } \\
\text { empty spikelets }\end{array}$ & 2.70 \\
\hline 2 & 'Jrashed ear & 10.92 \\
\hline 3 & $\begin{array}{l}\text { Internode between } 1 \text { st and } 2 \text { nd node. } \\
\text { counted down from above }\end{array}$ & iffi.?22. \\
\hline 4 & Internode between 2 nd and 3rd nokie & 45.32 \\
\hline 5 & Culm below sird node & 49.60 \\
\hline
\end{tabular}

Data in Table 5 indicate that on the residual grains population of the nematode is extremely dense, both in total and living numbers. With respect to culms, difference in numbers of living nematode due to height difference is not found, while the number of total nematodes is small on the thrashed ear. 
Table 5. Distribution of the nematode on straw of affected rice plants, examined at the beginning of the next season.

\begin{tabular}{|c|c|c|c|c|c|c|c|c|c|c|}
\hline & \multicolumn{5}{|c|}{$\begin{array}{c}\text { Number of nematode } \\
\text { living }\end{array}$} & \multicolumn{5}{|c|}{$\begin{array}{l}\text { Number of } \\
\text { total nematodes }\end{array}$} \\
\hline & (ii) & 2 & 3 & 4 & 5 & 1 & 2 & 3 & 4 & 5 \\
\hline & 30 & 0 & 0 & 0 & 0 & 32 & 0 & 9 & 4 & 6 \\
\hline & 28 & 1 & 0 & 0 & 0 & 36 & 1 & 3 & 3 & 5 \\
\hline & 30 & 0 & i) & 0 & 0 & 36 & 0 & 13 & 3 & 10 \\
\hline & 33 & 3 & 0 & 0 & 0 & 40 & 3 & 7 & 7 & 8 \\
\hline & 23 & 0 & 2 & 0 & 1) & 28 & 0 & 6 & 4 & 6 \\
\hline & 29 & 0 & 0) & 0 & 0 & 32 & 0 . & 4 & 4 & 2 \\
\hline & 36 & $\theta$ & 1 & 0 & 0 & 38 & 0 & 6 & 6 & 6 \\
\hline & 23 & 1. & 1 & 0 & 0 & 28 & 1 & 8 & 5 & 7 \\
\hline & 26 & 1 & 2 & 0 & 0 & 32 & 1 & 5 & 2 & 4 \\
\hline & 28 & 2 & 0 & 1 & 0 & 32 & 2 & 3 & 3 & A \\
\hline Total & 287 & 8 & 6 & 1 & 0 & 334 & 8 & 64 & 41 & 60 \\
\hline
\end{tabular}

a) Meaning of the figure is given in Table 4 .

$D \geqslant 17.5$ Difference between any two of totals of living nematodes, significant at 5 per cent level.

D) 23.6 Difference between any two of totals of total nematodes, significant at 5 per cent level.

\section{LONGFVITY OF THE NFMATODE WITHIN UNHUI.TED-GRAIN}

It may be not in vain to test the longevity of the nematode stuck to the hulls, even though rice grain held for two years is usually not used for secd because of its poor germinating power.

In November 1948, the diseased seed came from Fukuoka Station in autumn 1945 and that from Saga Station in the same year were compared with the seed of the current season obtained at Hakozaki. The nematodes both living and dead were counted on these samples as usual. The results summerized in Table 6 show that the longevity of the nematode within unhulled-grain is more than thre years, though the number of living nematodes is somewhat decreased in comparison with that of the current scason. 
Table 6 . Longevity of the nematode within unhulled.grain, tested in Nov. 1948.

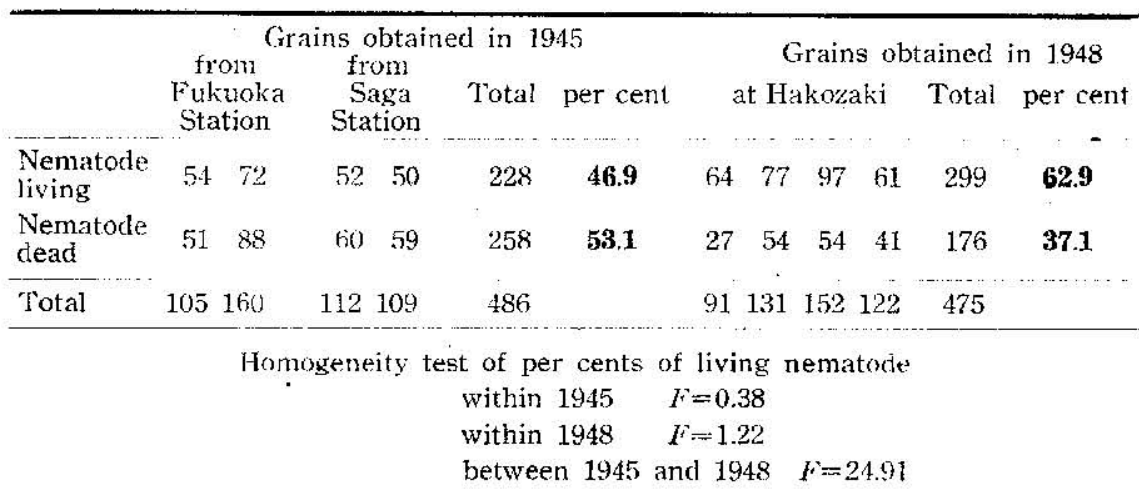

Searcilfs for the Host Plants other than Rice AND I'TALIAN MillileT

a) Infection experiment with Aphelenchoides oryzae to Foxtail (Setaria viridis Beauv.).

In May 1948, Fox-tail was sown in a pot mixed with the rice grain affected by the nematode disease. After one month, the seedlings of these plants were picked up and planted separately. In September, the present nematode was found, though scanty in number, on the ear of Fox-tail inoculated. No symptom had been observed on the infected plants.

After it became ripe, the ears of Fox-tail wer' gathered, and the nematode number per 20 grains was counted under microscope as usual. The results thus obtained (Table 7 ) show that the

Table 7. Dccurrence of Aphelenchoides oryzac in grains of Fox.tail (Setaria viridis) infected with the nematode. 25 replicates of 20 grains each.

\begin{tabular}{|c|c|c|c|}
\hline \multicolumn{2}{|c|}{$\begin{array}{l}\text { Nematodes in } \\
\text { fox-tail grain }\end{array}$} & \multicolumn{2}{|c|}{$\begin{array}{l}\text { Nematodes in rice } \\
\text { grains (infection source }\end{array}$} \\
\hline Living & Total & Livin & Total \\
\hline 0 & 2 & 7 & 8 \\
\hline 1 & 5 & 0 & 0 \\
\hline 1 & 1 & 13 & 20 \\
\hline 0 & 0 & 4 & 4 \\
\hline 11 & 1 & 8 & 13 \\
\hline
\end{tabular}




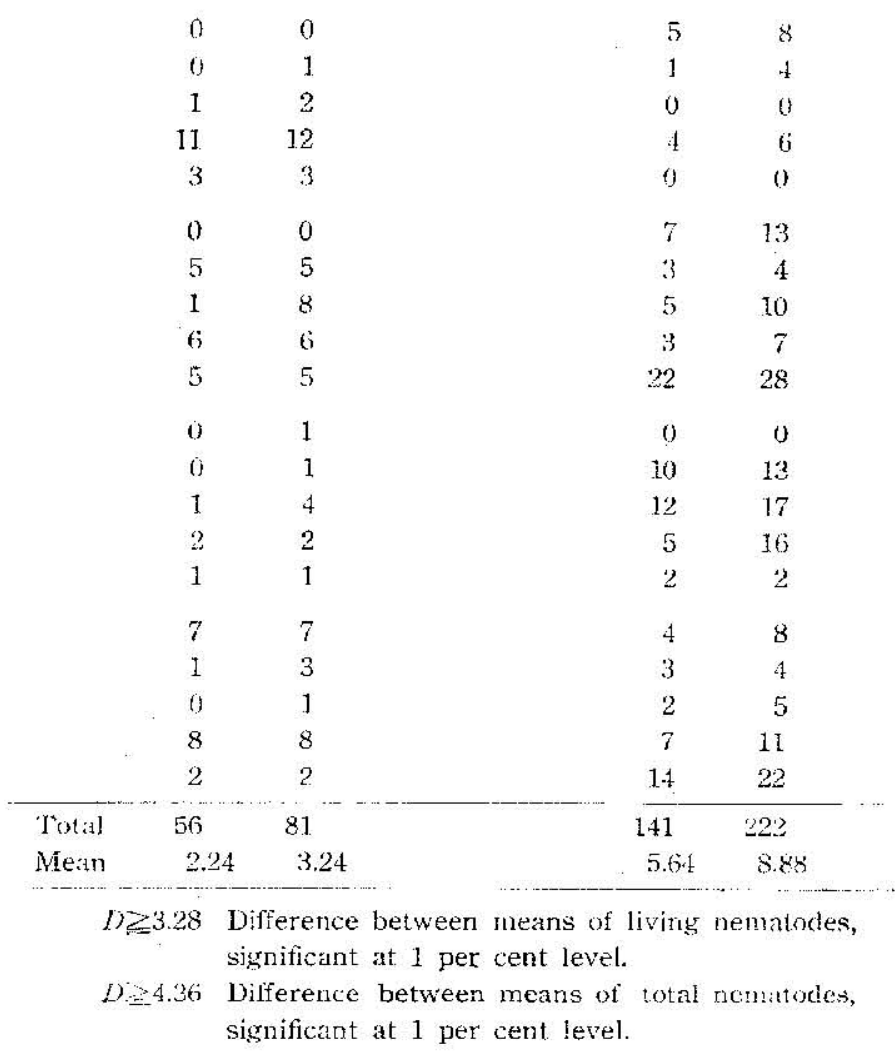

nematode is able to infect Setaria viridis, though its population on the ear is thinner than that of the original diseased rice used for the experiment.

b) Occurrence of the nematode on the ear of weeds grown within plots of affected plants.

In autumn 1948 a large number of the nematode were found on the ear of Fox-tail (Setaria viritis) grown between hills of Italian millet which were heavily affected by the disease. Meanwhile, the nematode was found on the ear of Crab grass (Panicum sanguinale $\mathrm{T}_{\text {..) }}$ grown at the same place; and also it was found on the ear of Cyperus grass (Cyperus iria L.) grown within a hill of rice plant affected heavily by the nematode disease. It may be probable that the occurrence of the nematode on these weeds was 
brought abou1 by rain drops in which the pathogens migrated from ears of the affected crops.

The seed grains of these plants grown under diseased crops were gathered, together with those obtained from way-side, were dried and preserved until the following spring, when they were counted for their nematodes. The results obtained are given in Table 8.

Table \&. Occurrence of the nematode within preserved seed of several weeds, examined at the beginning of next season.

\begin{tabular}{|c|c|c|c|c|c|c|c|c|}
\hline Weeds & Localities & $\begin{array}{l}\text { No. of } \\
\text { srains } \\
\text { tested } \\
\text { (ca.) }\end{array}$ & & $\begin{array}{l}\text { c. of } \\
5\end{array}$ & ne & it & & \\
\hline Setaria viridis : & $\begin{array}{l}\text { Under diseased } \\
\text { Italian millet }\end{array}$ & 70 & $\left\{\begin{array}{l}\text { Living } \\
\text { Dead }\end{array}\right.$ & $\begin{array}{r}10 \\
4\end{array}$ & $\begin{array}{r}13 \\
1\end{array}$ & $\frac{5}{5}$ & $\begin{array}{l}7 \\
2\end{array}$ & 17 \\
\hline Panicum sanguinale & ditto & 50 & $\left\{\begin{array}{l}\text { Living } \\
\text { Dead }\end{array}\right.$ & $\begin{array}{l}1 \\
2\end{array}$ & $\begin{array}{l}0 \\
1\end{array}$ & $\begin{array}{l}1 \\
3\end{array}$ & $\frac{\mathrm{i}}{5}$ & $\begin{array}{l}2 \\
2\end{array}$ \\
\hline Cyperus iria & $\begin{array}{l}\text { Under diseased } \\
\text { rice plant }\end{array}$ & 100 & $\left\{\begin{array}{l}\text { Living } \\
\text { Dead }\end{array}\right.$ & $\begin{array}{l}0 \\
1\end{array}$ & 3 & $\begin{array}{l}0 \\
1\end{array}$ & $\begin{array}{l}0 \\
1\end{array}$ & $\begin{array}{l}0 \\
0\end{array}$ \\
\hline Setaria viridis al & Way-side & 70) & $\left\{\begin{array}{l}\text { Living } \\
\text { Dead }\end{array}\right.$ & $\begin{array}{l}0 \\
0\end{array}$ & $\begin{array}{l}0 \\
1\end{array}$ & 0 & 0 & $\begin{array}{l}0 \\
0\end{array}$ \\
\hline Panicum sanguindele & dit(r) & 50 & $\left\{\begin{array}{l}\text { Living } \\
\text { Dead }\end{array}\right.$ & $\begin{array}{l}0 \\
4\end{array}$ & 0 & 0 & 0 & $\begin{array}{l}0 \\
0\end{array}$ \\
\hline Cypenus iria & ditto & 100 & $\left\{\begin{array}{l}\text { Living } \\
\text { Dead }\end{array}\right.$ & 0 & 0 & $\begin{array}{l}0 \\
0\end{array}$ & $\begin{array}{l}0 \\
0\end{array}$ & $\begin{array}{l}0 \\
0\end{array}$ \\
\hline
\end{tabular}

a) A nematode belonging under Cephalobus is often found.

It is obvious that the nematodes are left alive until the following season within dry seed of Fox-tail (Setaria viridis) and sometimes of Crab grass, both having come from the plot of diseased Italian millet. While the living nematodes ate not found in the seed of Cyperus grass collected at the hill of diseased rice, they were found on the flowers in the preceding autumn. Within the sced of these weeds collected by the wayside, except for Foxtail, the nematode was not found. It is worthy to note that the nematode existed, though scarce in number, on the ear of Fox-tail collected by the way-side.

In an other experiment no nematode was found on the ear of Barnyard grass (Panicum crus-galli) collected at heavily affected paddy field. Again, at the infection experiments of the nematode to Barnyard grass negative results were obtained. 
These data show that the nematode may often be found, sometimes remaining alive, in the seed of some weeds which grow in the field of affected rice or Italian millet, even if the weeds are not the true host plants for the pathogen, and that the most noteworthy grass is Setaria viridis.

\section{Hibernation of the Present nematodi: in Field}

In January 1949, unhulled rice grains heavily infected with the present nematode were divided into four paris, each covered with cheesecloth, placed out of doors as follows:-1) put into water, 2) placed on the surface of the untilled dry rice field, 3) inserted in ridge of the same field, and 4) preserved in dry state for control. After four months these samples were gathered, dried for a few days, and then the number of the nematode within each of them was counted.

The results given in Table 9 show that all of the living nematodes have vanished from the grain treated. with some exception kept in soil, and that there is a sharp difference between the preserved control and the treated grains, on the numbers of the nematodes both of living or total.

Table 3. Numbers of nematodes exist within unhulled-grains: left out of doors, January to May.

25 replicates of 10 grains each.

\begin{tabular}{cccccccc}
\hline $\begin{array}{c}\text { Crrains in water } \\
\text { Living }\end{array}$ & $\begin{array}{c}\text { Trains on ground } \\
\text { nema. }\end{array}$ & Living & Gotal & Grains in soil & \multicolumn{2}{c}{$\begin{array}{c}\text { Grains in dry } \\
\text { state (Chech) }\end{array}$} \\
\hline 0 & 0 & 0 & 0 & 1 & 2 & 4 & 12 \\
0 & 0 & 0 & 0 & 0 & 0 & 36 & 38 \\
0 & 0 & 0 & 1 & 0 & 0 & 10 & 43 \\
0 & 1 & 0 & 0 & 0 & 0 & 17 & 19 \\
0 & 0 & 0 & 0 & 0 & 0 & 27 & 35 \\
0 & 0 & 0 & 0 & 0 & 0 & 23 & 25 \\
0 & 0 & 0 & 0 & 0 & 0 & 20 & 24 \\
0 & 0 & 0 & 0 & 0 & 0 & 13 & 14 \\
0 & 0 & 0 & 0 & 1 & 1 & 10 & 14 \\
0 & 0 & 0 & 0 & 0 & 0 & 6 & 9
\end{tabular}




\begin{tabular}{rrrrrrrrr}
0 & 0 & 0 & 0 & 0 & 0 & 11 & 11 \\
0 & 1 & 0 & 0 & 0 & 0 & 8 & 9 \\
0 & 0 & 0 & 0 & 0 & 0 & 16 & 24 \\
0 & 0 & 0 & 0 & 0 & 0 & 8 & 9 \\
0 & 0 & 0 & 0 & 0 & 0 & 15 & 18 \\
0 & 0 & 0 & 0 & 0 & 0 & 16 & 22 \\
0 & 0 & 0 & 0 & 0 & 0 & 1 & 1 \\
0 & 0 & 0 & 0 & 0 & 0 & 9 & 11 \\
0 & 0 & 0 & 0 & 1 & 1 & 8 & 10 \\
0 & 0 & 0 & 0 & 0 & 0 & 7 & 9 \\
0 & 0 & 0 & 0 & 0 & 0 & 11 & 20 \\
0 & 0 & 0 & 0 & 0 & 0 & 22 & 32 \\
0 & 0 & 0 & 0 & 0 & 0 & 8 & 13 \\
0 & 0 & 0 & 0 & 0 & 0 & 6 & 7 \\
\hline Total & 0 & 0 & 0 & 0 & 0 & 0 & 17 & 15 \\
\hline
\end{tabular}

From other experiments it is known that the nematode moves vigorously at a temperature ranging from $20^{\circ}$ to $25^{\circ} \mathrm{C}$. and scarcely moves when below $10^{\circ} \mathrm{C}$, and that the longevity of the nematode in water is less than 30 days at $20^{\circ}$ to $25^{\circ} \mathrm{C}$. From these facts, together with the disorganized state of the dead remainders in the present experiment, it is reasonable to say that the most of the nematode within the grains left out of doors would have perished due mainly to the attack of microorganisms, and would have disappeared before the time of examination.

From these facts it may be certain, in general, that the nematodes within grain or straw scattered over the field at harvest, or the nematodes remain on some grass, will be decomposed and will disappear from the field before the beginning of the next season.

\section{SuMmary}

The nematode can infect Italian millet and a sort of Fox-tail (Selaria viridis). Barnyard grass (Panicum crus-galli) is not the host plant.

The nematode situates exo-parasitic within the folded youngest leaf of rice before the formation of the youngest ear. After the youngest ear is formed, it is found most frequently within the 
pubescence of the ear, but sometimes it enters the inner side of the young flowering glume. From the caring to the flowering stage, it is found commonly on the ear- outside of the flowering glume. At the flowering stage it usually enters the inner side of the flowering glume, and is found stuck to the inner wall of flowering glume until next spring.

The number of the nematode found on well-developed unhulledgrain is larger than that on waste unhulled-grain.

Examination of the distribution of the nematode on rice straw at the beginning of the next season, indicates that the population of the nematode is extemely dense on the residual grain. On straw after perfect thrashing, there were found no significant differences in numbers of living nematode due to height difference.

The nematode could hardly survive the winter when unhulledgrain is scattered in the field.

\section{LITHRATURE CITLD}

Fukano, H., Yokoyana, S., 1947, 14th annual meeting of Plant Protection Soc. Kyusha, at Beppu, Nov. 1947 (Speech). 